\title{
PENGELOLAAN LAHAN BASAH TERKAIT SEMAKIN MARAKNYA KEBAKARAN DENGAN PENDEKATAN ADAPTASI YANG DIDASARKAN PADA KOVENSI RAMSAR
}

Oleh :

Fitri Ramdhani Harahap, S.Sos., M.Si

\begin{abstract}
Abstrak :
Lahan basah tidak saja dipahami sebagai pendukung kehidupan secara langsung, seperti sumber air minum dan habitat beraneka ragam mahluk, tapi juga memiliki berbagai fungsi ekologis seperti pengendali banjir, pencegah intrusi air laut, erosi, pencemaran, dan pengendali iklim global. Salah satu bentuk kerusakan lahan basah yang semakin banyak terjadi adalah kebakaran gambut mudah terjadi di hutan rawa gambut tropis. Akibatnya hutan yang telah dieksploitasi dan tajuknya relatif lebih terbuka karena terganggu mengalami kekeringan dan mudah terbakar, ditambah lagi adanya kegiatan penyiapan lahan dengan pembakaran yang dilakukan oleh peladang berpindah. Konvensi Ramsar adalah perjanjian internasional untuk konservasi dan pemanfaatan lahan basah secara berkelanjutan. Indonesia masuk menjadi anggota Konvensi Ramsar pada tahun 1991 dengan diterbitkannya Keppres 48 Tahun 1991 yang merupakan Ratifikasi Konvensi Ramsar di Indonesia. Strategi adaptasi dapat membantu manusia dalam mengelola dampak perubahan iklim dan melindungi sumber penghidupan atau matapencaharian mereka. Salah satu program yang telah dijalankan dalam upaya mengelolan lahan basah dengan pendekatan adaptasi adalah Program Adaptasi dan Mitigasi Lahan Basah Berkelanjutan (Sustainable Wetlands Adaptation and Mitigation Program/ SWAMP). Kegiatan yang dilaksanakan antara lain penanganan kebakaran di daerah penyangga termasuk penanaman tanaman tahan api, peningkatan kesadaran masyarakat akan bahaya dan akibat kebakaran, dan juga program pengelolaan daerah tangkapan air untuk mencegah keringnya hutan rawa gambut.
\end{abstract}

\section{Kata Kunci :}

Lahan Basah, Kebakaran, Adaptasi, dan Konvensi Ramsar

\section{A. PENDAHULUAN}

Lahan Basah adalah "Daerah-daerah rawa, payau, lahan gambut, dan perairan; tetap atau sementara; dengan air yang tergenang atau mengalir; tawar, payau, atau asin; termasuk wilayah perairan laut yang kedalamannya tidak lebih dari enam meter pada waktu surut" (Konvensi Ramsar).
Lahan basah memiliki peranan yang sangat penting bagi kehidupan manusia. Fungsi lahan basah tidak saja dipahami sebagai pendukung kehidupan secara langsung, seperti sumber air minum dan habitat beraneka ragam mahluk, tapi juga memiliki berbagai fungsi ekologis seperti pengendali banjir, pencegah intrusi air laut, erosi, pencemaran, dan pengendali iklim global. 
Kawasan lahan basah juga akan sulit dipulihkan kondisinya apabila tercemar, dan perlu bertahun-tahun untuk pemulihannya. Dengan demikian, untuk melestarikan fungsi kawasan lahan basah sebagai pengatur siklus air dan penyedia air permukaan maupun air tanah perlu dilakukan pengelolaan kualitas air dan pengendalian pencemaran air secara bijaksana dengan memperhatikan keseimbangan ekologis dan kepentingan generasi sekarang dan mendatang.

Akumulasi pengelolaan lahan basah Indonesia yang keliru selama ini menyebabkan kerusakan yang sangat besar. Danau-danau di Sulawesi misalnya yang hingga 10 tahun lalu masih kaya akan ikan-ikan endemik kini didominasi oleh invasive alien spesies seperti Mujair. Kualitas air pada berbagai kawasan lahan basah terutama sungai mengalami penurunan yang sangat signifikan, diperkirakan $60 \%$ sungai di Indonesia dalam keadaan tercemar. Jutaan hektar rawa gambut di Sumatera dan Kalimantan terbakar dalam kurun waktu 10 tahun terakhir dan menyebabkan kehancuran keanekaragaman hayati rawa gambut, kerusakan tata air kawasan, dan lepasnya jutaan ton karbon ke udara. Akibat berbagai tekanan tersebut, hingga tahun 1996 Wet-lands International-Indonesia Programme (WI-IP) memperkirakan Indonesia kehilangan lahan basah alami sekitar 12 juta ha. Kehilangan tersebut juga diperparah oleh tingginya kegiatan perambahan hutan dan alih fungsi lahan basah menjadi pemukiman, industri, pertanian, dan perkebunan.

Kerusakan-kerusakan yang terjadi secara langsung atau tidak langsung akan berpengaruh pada kehidupan sosial ekonomi masyarakat seperti meningkatnya angka kemiskinan serta menurunnya tingkat pendidikan dan kualitas hidup. Untuk itu diperlukan upaya sesegera mungkin untuk memperbaiki kondisi tersebut dengan meningkatkan komunikasi dan koordinasi antar para pemangku kepentingan melalui berbagai cara.

Dalam kurun waktu 1991-1996 terdapat tiga kegiatan penting yang berkaitan langsung dengan kebijakan pengelolaan lahan basah di Indonesia. Kegiatan pertama adalah ratifikasi Konvensi Ramsar (Convention of Wetlands Importance, Especially as Waterfowl Habitat) oleh pemerintah melalui Keputusan Presiden No. 48 Tahun 1991. Kegiatan kedua adalah pembentukan Komite Nasional Pengelolaan Ekosistem Lahan Basah (KNLB) tahun 1994 melalui Keputusan Menteri Kehutanan No. 226/Kpts-VI/94, yang terdiri dari beberapa instansi (lihat bagian Kelembagaan di Bab 4). Kegiatan ketiga adalah diterbitkannya buku The National Strategy and Action Plan for the Management of Indonesian Wetlands (Strategi Nasional dan Rencana Aksi Pengelolaan Lahan Basah Indonesia) oleh Pemerintah Indonesia (cq: Kantor Menteri LH dan Ditjen PHKA-Dephut) pada tahun 1996.

Salah satu bentuk kerusakan lahan basah yang semakin banyak terjadi adalah kebakaran gambut mudah terjadi di hutan rawa gambut tropis yang telah terdegradasi karena konversi dan pembukaan lahan, terutama yang melibatkan penebangan dan pembukaan kanal drainase. Hutan tropika basah Indonesia dikenal sebagai hutan yang selalu basah dan tahan terhadap kebakaran. Tetapi pada tahun 1982/1983, sekitar 3,6 juta ha hutan tropika basah di Kalimantan Timur terbakar. Pada saat itu terjadi fenomena El Nino dimana musim kering berkepanjangan melanda Indonesia dalam jangka waktu 10 bulan berturut-turut. Akibatnya hutan yang telah dieksploitasi dan tajuknya relatif lebih terbuka karena terganggu mengalami kekeringan dan mudah terbakar, ditambah lagi adanya kegiatan penyiapan lahan dengan pembakaran yang dilakukan oleh peladang berpindah yang kemudian menjadi 
salah satu pemicunya. Sejak saat itu, kebakaran terus berlanjut sampai terjadi kebakaran hutan dan lahan yang lebih luas pada tahun 1997/1998, dimana hampir 10 juta ha hutan dan lahan terbakar (Bappenas 1999; Taconi, 2003). Dampak yang ditimbulkan dari kebakaran tersebut adalah kabut asap yang menyelimuti kawasan regional ASEAN yang dikenal sebagai Transboundary Haze Pollution. Gambar 1 berikut menunjukkan distribusi hotspot sebagai indikator kebakaran hutan dan lahan di Indonesia tahun 1997 2013 yang menunjukkan fluktuasi (Saharjo dan Lailan).

Kebakaran hutan dan lahan Indonesia
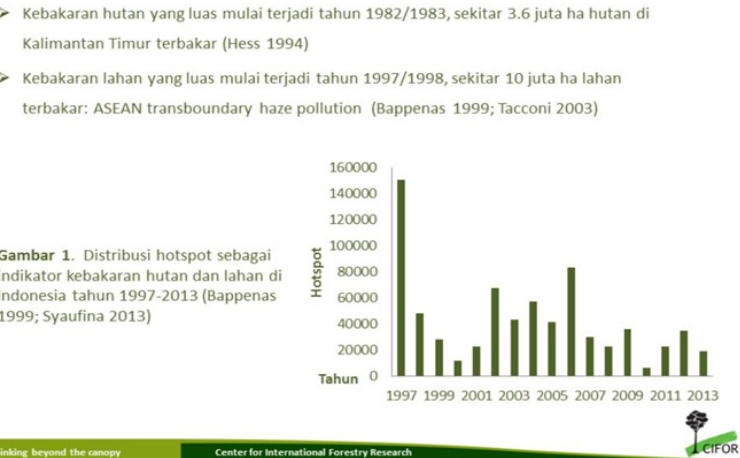

Gambar 2 menunjukkan distribusi hotspot di Indonesia pada periode 1997-2013 pada beberapa provinsi di Sumatera dan Kalimantan. Provinsi Riau menempati urutan dengan hotspot tertinggi yang diikuti oleh provinsi Kalimantan Tengah, Kalimantan Barat, dan Sumatera Selatan.

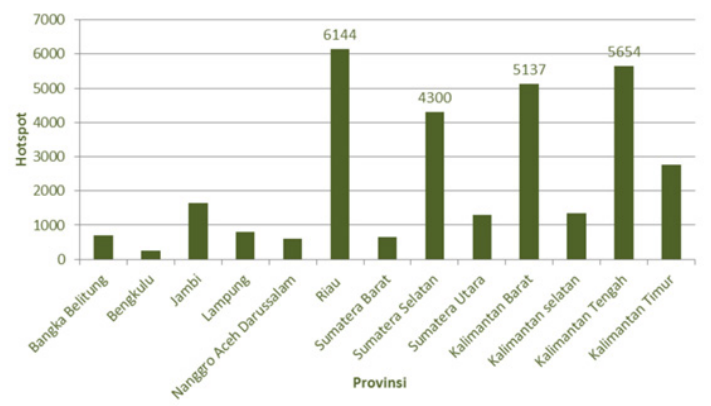

Gambar 2. Distribusi hotspot di Indonesia periode 1997-2013 (Bappenas 1999; Syaufina 2014)
Terbakarnya kawasan-kawasan rawa gambut telah merusak beberapa tempat penyimpanan karbon terpenting di dunia dan melepaskan sejumlah besar karbon ke udara. Sebuah studi memperkirakan bahwa karbon yang dilepas selama kebakarankebakaran lahan gambut pada tahun 1991/1998 sama jumlahnya dengan 13 sampai 40\% dari emisi tahunan yang disebabkan oleh pembakaran bahan baku fosil di seluruh dunia (Rahmayanti, 2007:109).

Data lain yang diungkapkan oleh Lorenzo dan Canesio, selama sembilan bulan dari September 1997 sampai Mei 1998, kebakaran di Indonesia khususnya di pulau Kalimantan dan Sumetara telah menghancurkan lebih dari 10 juta ha hutan dan areal bukan hutan. Total kerugian akibat kebakaran dan asap yang timbul dari kebakaran tersebut cukup mengejutkan, yaitu USD 3.8 miliar untuk Indonesia dan USD 0.7 miliar untuk negara-negara tetangga yang terkena dampaknya. Sementara total kerugian ekonomi yang dialami akibat kebakaran yang terjadi pada tahun 1997/1998, menurut perkiraan ADB paling sedikit adalah USD 8.549 miliar, dan maksimum mencapai USD 9.402 miliar. Beberapa penyebab kebakaran berdasarkan beberapa kajian yaitu :

1. Pembakaran yang dilakukan oleh pemilik perkebunan yang luas untuk menghilangkan biomasa yang tidak diinginkan selama persiapan lahan.

2. Pembakaran oleh penduduk yang miskin dan petani yang memiliki ladang kecil untuk membuka lahan.

Hutan tropika basah Indonesia dikenal sebagai hutan yang selalu basah dan tahan terhadap kebakaran. Tetapi pada tahun 1982/1983, sekitar 3,6 juta ha hutan tropika basah di Kalimantan Timur terbakar (Hess, 1994). Pada saat itu terjadi fenomena El Nino dimana musim kering 
berkepanjangan melanda Indonesia dalam jangka waktu 10 bulan berturut-turut. Akibatnya hutan yang telah dieksploitasi dan tajuknya relatif lebih terbuka karena terganggu mengalami kekeringan dan mudah terbakar, ditambah lagi adanya kegiatan penyiapan lahan dengan pembakaran yang dilakukan oleh peladang berpindah yang kemudian menjadi salah satu pemicunya. Sejak saat itu, kebakaran terus berlanjut sampai terjadi kebakaran hutan dan lahan yang lebih luas pada tahun 1997/1998, dimana hampir 10 juta ha hutan dan lahan terbakar (Bappenas 1999; Taconi, 2003). Dampak yang ditimbulkan dari kebakaran tersebut adalah kabut asap yang menyelimuti kawasan regional ASEAN.

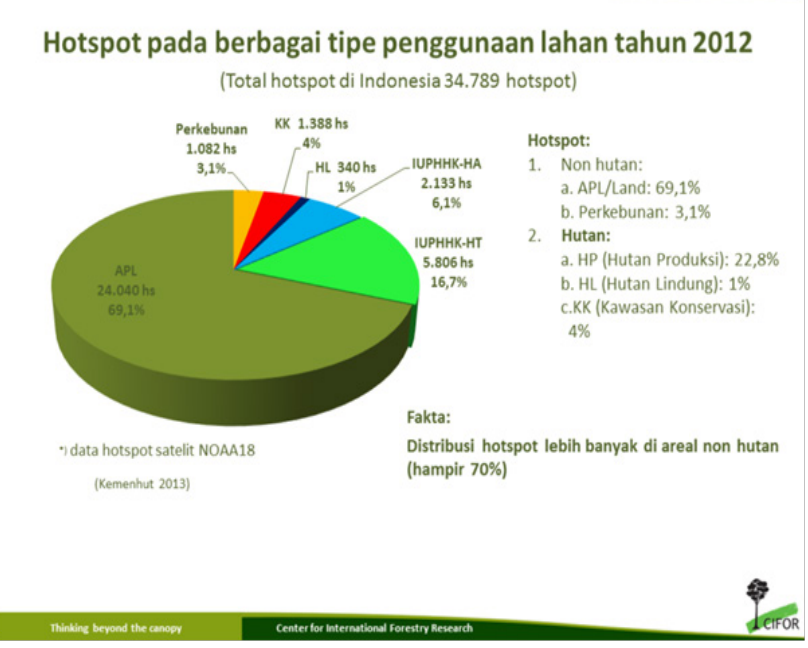

Hasil pengolahan data hotspot oleh Kementerian Kehutanan (2013) pada Gambar 3 di atas menunjukkan bahwa sampai dengan tahun 2012 hotspot lebih banyak ditemukan di kawasan non hutan/Areal penggunaan lain (APL) yang memang tidak berhutan yang didominasi oleh semak belukar dan areal relatif terbuka sehingga memungkinkan untuk open akses (hampir $70 \%$ ), hanya 20\% yang dijumpai di kawasan hutan.

\section{B. Titik Api atau Titik Panas (Hotspot) Ke- bakaran pada Lahan Basah}

Hotspot merupakan salah satu alat deteksi dini kebakaran. Kajian tentang kondisi kebakaran hutan dan lahan (khususnya kawasan hutan konservasi) secara makro seringkali tak bisa dipisahkan dari pembicaraan mengenai hotspot. Pengertian Titik Api atau Titik Panas (hotspot) sendiri adalah suatu indikator kebakaran hutan yang mendeteksi suatu lokasi yang memiliki suhu relatif lebih tinggi dibandingkan dengan suhu disekitarnya (Permenhut nomor P.12 tahun 2009). Gambar 4 berikut adalah contoh titik api atau titik panas yang didapatkan dari Google Earth, dimana archieve data hotspot dapat didownload di alamat : https://earthdata.nasa.gov/data/near-real-time-data/firms/active-fire-data\#tab-content-2

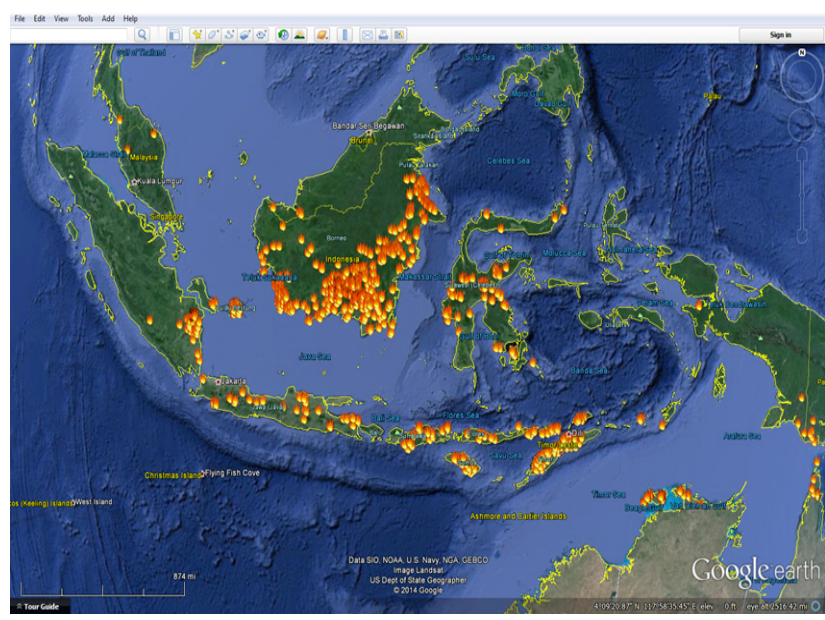

Menurut Yonatan (2006) deteksi kebakaran hutan merupakan salah satu kegiatan yang penting dalam rangka pengendalian kebakaran hutan. Salah satu adalah deteksi keberadaan titik panas (hotspot) lapangan. Cara deteksi Titik panas (hotspot) dapat dideteksi dengan satelit NOAA (National Oceanic and Atmospheric Administration), yang dilengkapi dengan sensor AVHRR (Advanced Very High Resolution Radiometer). Sensor ini bekerja berdasarkan pancaran energi termal dari obyek yang diamati. Suatu areal yang bersuhu $42{ }^{\circ} \mathrm{C}$, dapat mengindikasikan adanya titik panas (hotspot). Adanya titik panas (hotspot) belum tentu ada kebakaran, namun jika ada kebakaran, pasti ada titik panas. Suhu awal kebakaran berkisar antara $300-350^{\circ} \mathrm{C}$, suhu ini 
sekaligus merupakan suhu penyulutan dalam kebakaran hutan. Sebaran titik panas bulanan merupakan kumpulan titik panas yang terpantau dalam satu bulan. Satelit NOAA melakukan pemantauan satu hingga tiga kali dalam sehari dan terbagi dalam tiga wilayah, yaitu untuk pemantauan seluruh wilayah Sumatera dan Kalimantan, hanya wilayah Sumatera dan hanya wilayah Kalimantan.

Pada periode kebakaran hutan antara bulan Juli sampai Oktober 1997, Sumatera mengalami dampak yang sangat serius. Dari 2308 titik api (hotspot) yang dilaporkan berasal dari pulau Sumatera, 1402 titik api (45\%) berada di Sumatera Selatan dan 440 (19\%) berasal dari Jambi (Lubis dan Suryadiputra, 2004:110). Sementara Kepala Badan Meteorologi Klimatologi dan Geofisika (BMKG) Stasiun Pekanbaru, Sugarin menyatakan Satelit Terra dan Aqua mendeteksi 308 titik panas atau hotspot, yang mengindikasikan kebakaran lahan dan hutan, tersebar di Pulau Sumatera. Riau menjadi penyumbang hotspot terbanyak dengan jumlah 122 titik. Daerah lainnya di Sumatera yang menjadi penyumbang hotspot adalah Sumatera Selatan dengan 59 titik, Jambi 58 titik, Sumatera Utara 25 titik, Sumatera Barat 19 titik, Bengkulu 10 titik, Bangka Belitung sembilan, Lampung lima titik dan Kepulauan Riau dengan satu titik panas. Sementara itu, lokasi paling banyak terdapat terdeteksi hotspot di Riau adalah di Kabupaten Pelalawan dengan 44 titik. Kemudian lokasi lainnya berada di Kabupaten Bengkalis dengan 17 titik, Kampar 16 titik, Indragiri Hulu 14 titik, Indragiri Hilir delapan titik, Dumai tujuh titik, Rokan Hilir lima titik, Kuantan Singingi empat titik, dan Rokan Hulu dua titik (Antara News, Minggu 26 Juli 2015).

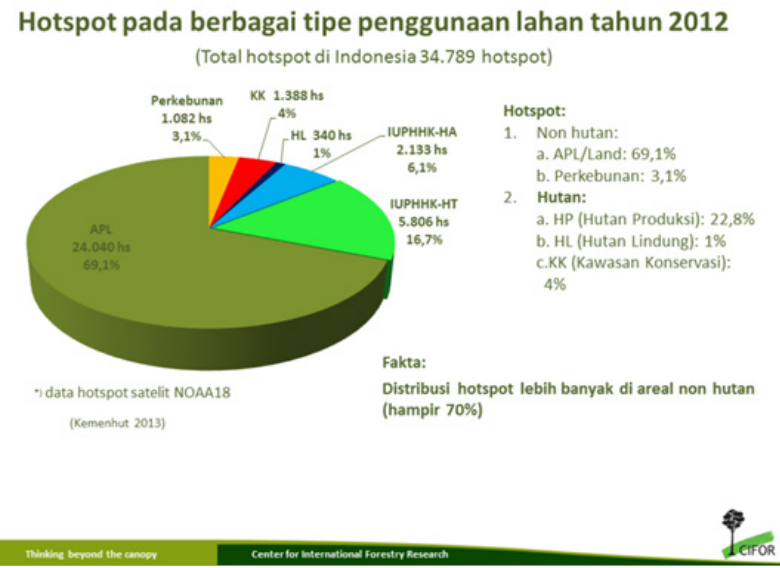

Hasil pengolahan data hotspot pada Gambar 5 oleh Kementerian Kehutanan (2013) menunjukkan bahwa sampai dengan tahun 2012 hotspot lebih banyak ditemukan di kawasan non hutan/ Areal penggunaan lain (APL) yang memang tidak berhutan yang didominasi oleh semak belukar dan areal relatif terbuka sehingga memungkinkan untuk open akses (hampir 70 \%), hanya $20 \%$ yang dijumpai di kawasan hutan.

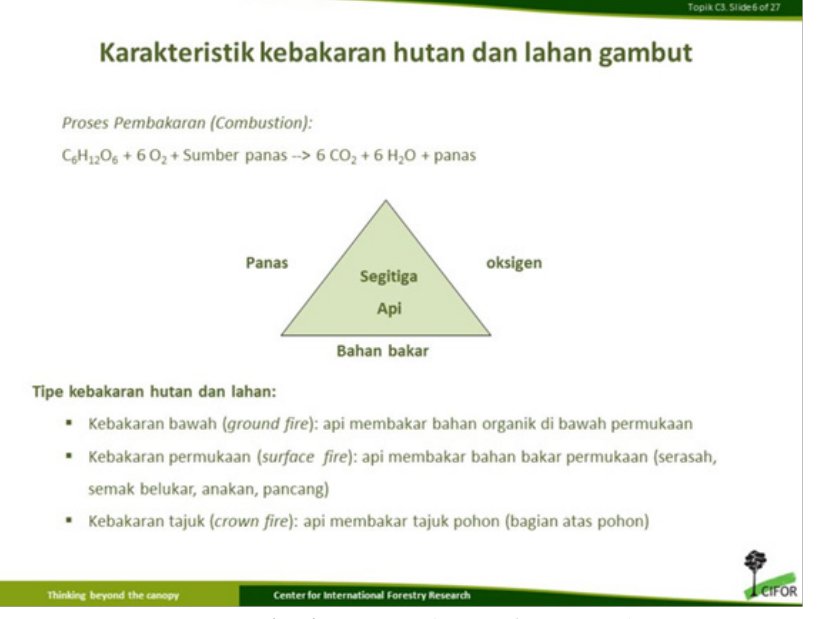

Proses pembakaran (combustion) merupakan kebalikan dari reaksi fotosintesis, dimana kebakaran hanya akan terjadi apabila unsur bahan bakar, oksigen dan panas sebagai unsur-unsur segitiga api bersatu. Berdasarkan tipe bahan bakar dan sifat pembakarannya, kebakaran hutan dan lahan dapat dikelompokkan menjadi tiga tipe (Gambar 6 dan 7), yaitu:

1. Kebakaran bawah (ground fire) merupakan tipe kebakaran dimana api membakar bahan 
organik di bawah permukaan;

2. Kebakaran permukaan (surface fire) yaitu tipe kebakaran dimana api membakar bahan bakar permukaan yang berupa serasah, semak belukar, anakan, pancang, dan limbah pembalakan;

3. Kebakaran Tajuk (crown fire) merupakan tipe kebakaran yang membakar tajuk pohon (bagian atas pohon).

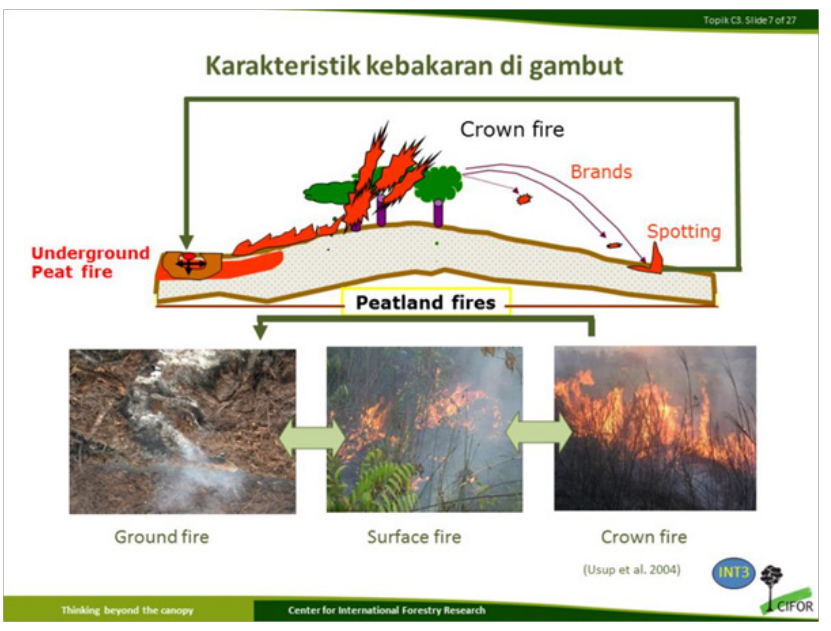

\section{Konvensi Ramsar (Ramsar Convention)}

Lahan basah merupakan sumber kehidupan yang sangat vital bagi seluruh mahluk hidup. Menyadari begitu besar manfaat dan fungsi lahan basah, beberapa perwakilan negara-negara di dunia telah menandatangani suatu kesepakatan untuk melestarikan lahan basah yang ada di bumi ini. Kesepakatan yang dikenal dengan Konvensi Ramsar ini tepatnya terjadi pada tanggal 2 Februari 1971 di kota Ramsar, Iran. Indonesia masuk menjadi anggota Konvensi Ramsar pada tahun 1991 dengan diterbitkannya Keppres 48 Tahun 1991 yang merupakan Ratifikasi Konvensi Ramsar di Indonesia. Setiap anggota Ramsar berhak mendaftarkan lokasi-lokasi lahan basahnya yang diakui memiliki kepentingan intenasional. Konvensi yang pada awalnya lebih berfokus pada masalah burung air dan burung migran, selanjutnya berkembang kepada kesadaran keutuhan lingkungan dan konservasi, termasuk keane- karagaman hayatinya, bahkan kesadaran tersebut saat ini lebih bermulti fokus menyangkut seluruh aspek kehidupan manusia (Triana, 2011:1).

Konvensi Ramsar adalah perjanjian internasional untuk konservasi dan pemanfaatan lahan basah secara berkelanjutan. Nama resmi konvensi ini adalah The Convention on Wetlands of International Importance, especially as Waterfowl Habitat. Konvensi Ramsar diratifikasi pemerintah Indonesia pada tahun 1991 melalui Keputusan Presiden RI No. 48 tahun 1991. Konvensi Ramsar disusun dan disetujui negara-negara peserta sidang di Ramsar, Iran pada tanggal 2 Februari 1971 dan mulai berlaku 21 Desember 1975. Sejumlah 1.889 lokasi lahan basah dengan luas keseluruhan $1.854 .370 \mathrm{~km}^{2}$ dimasukkan ke dalam Daftar Ramsar Lahan Basah Penting bagi Dunia. Lokasi lahan basah yang dilindungi Konvensi Ramsar disebut situs Ramsar. Negara yang memiliki situs Ramsar terbanyak adalah Britania Raya (168 situs), sedangkan Kanada memiliki situs Ramsar terluas dengan sekitar $130.000 \mathrm{~km}^{2}$ lahan basah, termasuk Teluk Queen Maud yang luasnya $62.800 \mathrm{~km}^{2}$. Sampai tanggal 2010 terdapat 159 negara penandatangan konvensi yang merupakan peningkatan dari sejumlah 119 negara pada tahun 2000, dan 18 negara pendiri pada tahun 1971 . Negara peserta konvensi bertemu setiap 3 tahun sekali di Konferensi Para Pihak yang pertama kali diadakan tahun 1980 di Cagliari, Italia. Amandemen disetujui di Paris (tahun 1982) dan di Regina (tahun 1987). Konvensi Ramsar memiliki komisi tetap, panel inspeksi keilmuan, dan sekretariat. Markas besar Konvensi Ramsar terletak di Gland,

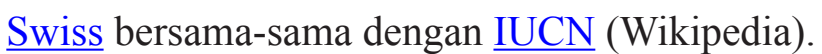

Isi konvensi lahan basah internasional berkaitan dengan perjanjian antar negara untuk berkomitmen pada perlindungan lahan basah yang bernilai penting bagi dunia internasional dan 
melakukan pemanfaatan secara bijaksana sumber daya alam hayati yang ada di dalamnya. Urgensi penanganan perjanjian ini terutama pada pengelolaan lahan basah yang secara ekologis membentang melintasi lebih dari satu negara, termasuk di dalamnya perlindungan terhadap burung air migran yang memiliki lintasan terbang antar negara. Di Indonesia sendiri telah terdapat 6 situs Ramsar, yaitu TN Rawa Aopa Watumohai Sulawesi Tenggara, TN Sembilang, TN Berbak, Danau Sentarum, TN Wasur dan Pulau Rambut.

\section{Pendekatan Adaptasi dalam Mengelola Kebakaran pada Lahan Basah}

Adaptasi (Adaptation) adalah tindakan penyesuaian oleh sistem alam atau manusia yang berupaya mengurangi kerusakan terhadap dampak yang ditimbulkan oleh perubahan iklim. Ketika iklim berubah, hutan dan manusia terpaksa harus terbiasa dengan perubahan curah hujan dan suhu udara yang terjadi secara perlahan. Mereka juga akan lebih sering menghadapi berbagai kejadian yang berkaitan dengan kondisi cuaca ekstrem seperti musim kering panjang dan banjir. Strategi adaptasi dapat membantu manusia dalam mengelola dampak perubahan iklim dan melindungi sumber penghidupan atau matapencaharian mereka. Adaptasi merupakan bidang baru dalam penelitian kebijakan hutan, namun demikian ada beberapa contoh yang dapat dilihat yaitu :

- Menjamin bahwa adanya luasan hutan dalam daerah tangkapan air dengan tutupan yang cukup untuk menahan erosi tanah dan dapat mengantisipasi curah hujan yang intensitasnya semakin tinggi akibat perubahan iklim.

- Menyediakan koridor hutan agar jenis tumbuhan dan satwa dapat berpindah atau dipindahkan ke suatu tempat atau ruang dengan iklim yang sesuai dengan keperluan

\section{hidupnya.}

- Membuat daerah penyangga (buffer zones) untuk menghentikan menjalarnya kebakaran hutan.

- Menanam jenis pohon yang lebih toleran terhadap suhu yang lebih tinggi dan cuaca ekstrem.

Sektor lain juga memiliki kepentingan dalam kebijakan adaptasi di sektor kehutanan. Contohnya, Departemen Perhubungan ingin menjaga hutan agar tetap sehat karena asap tebal akibat kebakaran hutan akan menutup bandara dan tanah longsor dapat menutup jalan. Penyedia air minum dan perusahaan Pembangkit Listrik Tenaga Air (PLTA) mulai mempertimbangkan pengelolaan ekosistem daerah hulu termasuk pengelolaan hutan. Pada dasarnya perusahaan-perusahaan tersebut ingin mengurangi kerentanan mereka terhadap pola curah hujan yang berubah dan menjamin terjaganya kualitas, kuantitas dan kontinuitas pasokan air bersihnya (CIFOR, 2010:2-3).

Salah satu program yang telah dijalankan dalam upaya mengelolan lahan basah dengan pendekatan adaptasi adalah Program Adaptasi dan Mitigasi Lahan Basah Berkelanjutan (Sustainable Wetlands Adaptation and Mitigation Program/ $S W A M P)$, dimana program ini melakukan pengukuran ekstensif dan terperinci atas cadangan karbon pada ekosistem mangrove yang relatif tidak terganggu dan atas fluks gas rumah kaca dari lahan gambut alami dan yang dikelola. Studi ini akan terus berlanjut untuk mendukung pengembangan berbagai model dan skenario. SWAMP antara lain akan menggunakan Lidar berbasiskan lapangan (untuk mengembangkan persamaan biomassa tanpa mengganggu ekosistem), radar penetrasi lapangan (untuk mengukur kedalaman gambut) dan merotasi tabel kemiringan permu- 
kaan (untuk mengukur penambahan dan pengurangan). SWAMP juga mengelola suatu jaringan kerja peneliti mangrove dan lahan gambut yang terus berkembang di dunia dan memberi peluang untuk peningkatan kapasitas. Bidang yang baru untuk SWAMP adalah menelaah isu-isu adaptasi pada ekosistem mangrove dan lahan gambut (CIFOR, 2014:9).

Program lain yang berhubungan dengan pengelolaan lahan basah dengan pendekatan adaptasi adalah pengembangan Rencana Pengelolaan Daerah Penyangga Taman Nasional Berbak selama tahun 1997-2000 oleh Pemerintah Daerah Jambi yang didanai oleh World Bank, mendapat dukungan dari PT. Amythas yang bekerjasama dengan Wetlands International-Indonesia Programme (WI-IP). Kegiatan yang dilaksanakan antara lain penanganan kebakaran di daerah penyangga termasuk penanaman tanaman tahan api, peningkatan kesadaran masyarakat akan bahaya dan akibat kebakaran, dan juga program pengelolaan daerah tangkapan air untuk mencegah keringnya hutan rawa gambut. Beberapa aktivitas yang telah direkomendasikan dalam dokumen tersebut pada Oktober 2000 yaitu kampanye penyadaran, peningkatan kapasitas pengelolaan kawasan, dan peningkatan status daerah Sembilang sebagai sebuah Tamana Nasional (Lubis dan Suryadiputra, 2004:111).

\section{E. Penutup}

Lahan basah merupakan pendukung utama kehidupan setiap mahluk. Air yang kita butuhkan sehari-hari terkandung di dalam ekosistem lahan basah, serta banyak lagi manfaat-manfaat lainnya yang diberikan lahan basah. Sebagai "penikmat" jasa lingkungan, manusia berupaya terus menerus menggali manfaat-manfaat yang terkandung di dalam lahan basah. Terkadang, pengelolaan dan pemanfaatannya justru tidak bersfiat bijak dan jangka panjang. Sebagai contoh kegiatan perambahan hutan dan alih fungsi lahan basah menjadi pemukiman, industri, pertanian, dan perkebunan dengan melakukan pembakaran.

Konvensi Ramsar kemudian diselenggarakan sebagai bentuk perjanjian antar negara agar berkomitmen pada perlindungan lahan basah yang bernilai penting bagi dunia internasional dan melakukan pemanfaatan secara bijaksana sumber daya alam hayati yang ada di dalamnya.

Upaya-upaya yang dapat dilakukan untuk mencegah kebakaran lahan adalah penyuluhan pencegahan kebakaran, membuat sekat bakar, melibatkan masyarakat setempat dalam penanggulangan kebakaran agar masyarakat memiliki rasa tanggungjawab terhadap kebakaran. 


\section{DAFTAR PUSTAKA}

CIFOR, 2010, REDD Apakah itu? Pedoman CIFOR tentang Hutan, Perubahan Iklim dan $R E D D$, Center for International Forestry Research, Tidak Dipublikasikan.

CIFOR, 2014, Prioritas Penelitian CIFOR $2013-$ 2014, Center for International Forestry Research, Tidak Dipublikasikan.

Ilman, Muhammad., 2008, Efektivitas Pengelolaan Kawasan Konservasi Lahan Basah Pesisir Indonesia. Disertasi. Sekolah Pascasarjana Institut Pertanian Bogor.

Kementrian Lingkungan Hidup, 2004, Strategi Nasional dan Rencana Aksi Pengelolaan Lahan Basah, Komite Nasional Penanggulangan Ekosistem Lahan Basah, Perpustakaan Nasional : Katalog Dalam Terbitan (KDT).

Lorenzo, Eliezer P., Canesio P. Munoz, Pembukaan Lahan tanpa Pembakaran-Sebuah Model Pembukaan Lahan tanpa Bakar dalam Mempersiapkan Pembangunan Hutan Tanaman di Indonesia, http://www.cifor. org/publications/pdf files/Books/BSuyanto0301I4.pdf, diakses pada tanggal 8 September 2015.

Lubis, Irwansyah Reza, I.N.N. Suryadiputra, 2004, Upaya Pengelolaan Terpadu Hutan Rawa Gambut Bekas Terbakar di Wilayah Berbak-Sembilang, Prosiding Semiloka Kebakaran di Lahan Rawa/Gambut di Sumatera: Masalah dan Solusi, Center for International Forestry Research, Bogor.

Massal, Febrasius, dkk., 2014, Laporan Kerja Teknis Monitoring Hotspot dan Investgasi Kebakaran di Wilayah Kerja KFCP, Kalimantan Forests and Climate Partnership. Tidak Dipublikasikan.

Rahmayanti, Maya, Kontribusi Kebakaran Lahan Gambut Terhadap Pemanasan Global,
Jurnal Kaunia, Vol. III, No.2, Oktober 2007, hal. 101-117.

Saharjo, Bambang Hero., Lailan Syaufina, Kebakaran Hutan dan Lahan Gambut, Center for International Forestry Research, http:// www.cifor.org/ipn-toolbox/wp-content/uploads/pdf/C3.pdf, diakses pada tanggal 8 September 2015.

Triana, 2011, Forests for Water and Wetlands, Laporan Kegiatan Peringatan Hari Lahan Basah Sedunia 2Februari 2011. Tidak Dipublikasikan.

Yonatan, Daniel., 2006, Studi Sebaran Titik Panas (Hotspot) Sebagai Indikator Kebakaran Hutan dan Lahan di Propinsi Jambi, Skripsi, Program Studi Budi Daya Hutan Fakultas Kehutanan Institut Pertanian Bogor.

\section{Peraturan}

Peraturan Menteri Kehutanan Nomor P.12/Menhut-II/2009 Tentang Pengendalian Kebakaran Hutan.

\section{Situs Internet}

http://www.wetlands.org/Aboutus/tabid/54/Default.aspx, diakses pada tanggal 9 September 2015.

http://indonesia.wetlands.org/RAMSAR/tabid/3741/language/id-ID/Default.aspx, diakses pada tanggal 9 September 2015.

http://www.ramsar.org/about/the-ramsar-convention-and-its-mission, diakses pada tanggal 10 September 2015.

https://id.wikipedia.org/wiki/Konvensi Ramsar, diakses pada tanggal 9 September 2015. 